\title{
Correction to: A life cycle environmental sustainability analysis of microbial protein production via power-to-food approaches
}

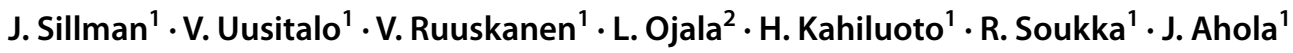

Published online: 13 December 2021

(c) The Author(s) 2021

\author{
Correction to: The International Journal of Life Cycle \\ Assessment (2020) 25:2190-2203 \\ https://doi.org/10.1007/s11367-020-01771-3
}

We found an unfortunate error in our article "A life cycle environmental sustainability analysis of microbial protein production via power-to-food approaches." The error can be found from Table 2, where we used a reference value of water use for soybean production to compare different environmental impacts of different protein sources. The presented reference value of water use of soybean should be 6301 per $\mathrm{kg}$ protein instead of 0.631 per kg protein.

Due to the error in Table 2, the text also contains an error. The error can be found from the Sect. 3.1.5. "When comparing impacts of best-case system modifications for bacterial MP produced via PtF in Cyprus to the impacts of other protein sources taken from literature (Sect. 2.2.7; Table 2), it can be seen that PtF-based MP production causes minimal environmental impacts with only the life cycle blue-water consumption being higher than that of soybean protein production." As the water use of soybean production is significantly higher than water use of MP production, it can be stated that the MP production have minimal environmental impacts in all studied impact categories. For other parts of the article, the error does not have an influence.

The original article has been corrected.

Open Access This article is licensed under a Creative Commons Attribution 4.0 International License, which permits use, sharing, adaptation, distribution and reproduction in any medium or format, as long as you give appropriate credit to the original author(s) and the source, provide a link to the Creative Commons licence, and indicate if changes were made. The images or other third party material in this article are included in the article's Creative Commons licence, unless indicated otherwise in a credit line to the material. If material is not included in the article's Creative Commons licence and your intended use is not permitted by statutory regulation or exceeds the permitted use, you will need to obtain permission directly from the copyright holder. To view a copy of this licence, visit http://creativecommons.org/licenses/by/4.0/.

Publisher's Note Springer Nature remains neutral with regard to jurisdictional claims in published maps and institutional affiliations.

The original article can be found online at https://doi.org/10.1007/ s11367-020-01771-3.

J. Sillman

jani.Sillman@lut.fi

1 School of Energy Systems, Sustainability Science, LUT University, P.O. Box 20, 53851 Lappeenranta, Finland

2 VTT Technical Research Centre of Finland, P.O. Box 1000, FI-02044 Espoo, VTT, Finland 